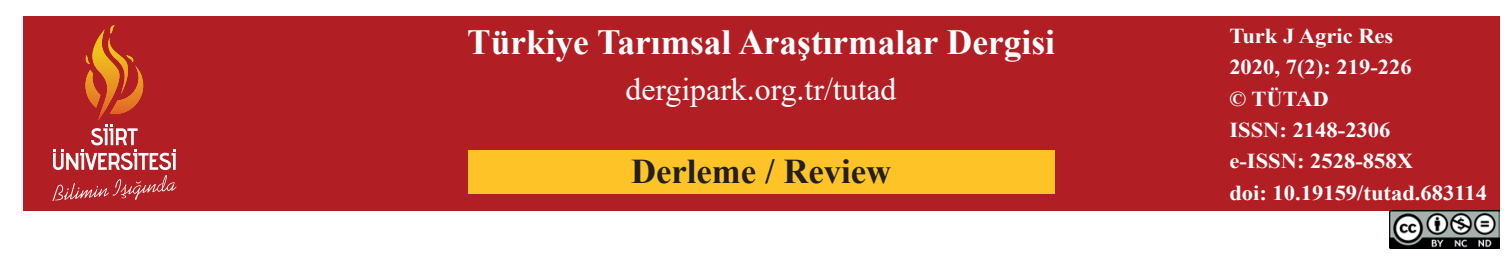

\title{
Brassica Türlerinde Şalgam Mozaik Virüsü (TuMV)’ne Dayanıklılık
}

\author{
Abdullah BALTACI ${ }^{1}$, Nuran CANSIZ ${ }^{2}$, Mehmet Ali ŞEVIK ${ }^{2 *}$ \\ ${ }^{1}$ Karadeniz Tarrmsal Araşttrma Enstitüsü Müdürllüğ̈, Bitki Sağllğı Bölümü, Samsun, TÜRKIYE \\ ${ }^{2}$ Ondokuz Mayıs Üniversitesi, Ziraat Fakültesi, Bitki Koruma Bölümü, Samsun, TÜRKIYE
}

\begin{tabular}{|c|c|}
\hline Geliş Tarihi/Received: 31.01 .2020 & Kabul Tarihi/Accepted: 30.05 .2020 \\
\hline \multicolumn{2}{|c|}{ ORCID ID (Yazar surasuna göre / by author order) } \\
\hline (1D) orcid.org/0000-0002-0309-5215 (1) orcid.org/0000-0003-3 & cid.org/0000-0002-8895-7944 \\
\hline
\end{tabular}

Öz: Brassicaceae familyası sebzeler, yağ bitkileri ve süs bitkileri gibi ekonomik öneme sahip bitkileri içermektedir. Şalgam mozaik virüsü (TuMV), ekonomik açıdan önemli birçok Brassica türünü tehdit eden bir virüstür. Özellikle Brassica grubu bitkileri arasında oldukça geniş bir konukçu dizisine sahip olup 156 cinse bağl1 318 bitki türünde enfeksiyon oluşturabilmektedir. Yürütülen kapsamlı çalıșmalarla, Brassica rapa (retr01, ConTR01, BcTuR3, rnt1, TuRBCH01, retr02, trs, TuMV-R, TuRB01b, TuRB07, TuRBCS01), B. napus (TuRB01, TuRB02, TuRB03, TuRB04, TuRB05) ve B. juncea (TuRBJU01, retr03)'da dominant ve resesif genler tespit edilmiştir. Yapılan çalışmalar, TuMV'ye dayanıklığın genetik mekanizması konukçuya ve patojen ırkına bağlı olduğunu göstermektedir. Ortaya çıkarılan dayanıklılık genlerinin Brassica türlerinde ıslah çalışmalarında kullanılması hastalıkla mücadele açısından oldukça önemlidir. Özellikle dünyada ve Türkiye'de önemli kışlık sebzelerden biri olan lahana (B. oleracea)'da TuMV'ye dayanıklı genlerin tanımlanarak haritalanması TuMV enfeksiyonuna bağlı kayıpların önlenmesi bakımından gereklidir. Bu nedenle lahanalarda TuMV'ye dayanıklılık mekanizmasıyla ilgili çalışmalara ihtiyaç duyulmaktadır. Genetik ve moleküler biyolojide sağlanan gelişmelerle Brassica ve TuMV arasındaki ilişkinin moleküler düzeyde araştırılması, dayanıklık mekanizmasının anlaşılması ve yeni dayanıklılık kaynaklarının ortaya konması açışıdan önemli olacaktır. Bu derleme TuMV'ye karşı Brassica türlerinde dayanıklılık sağlayan genler ve dayanıklılık mekanizmaları hakkında bilgilerin oraya çıkarılması amacıyla hazırlanmıştır.

Anahtar Kelimeler: Brassica, dayanıklılık genleri, dayanıklılık mekanizması, virüs, Şalgam mozaik virüsü

\section{Resistance to Turnip Mosaic Virus (TuMV) in Brassica Species}

\begin{abstract}
Brassicaceae family includes economically important plants such as vegetables, oil plants, and ornamental plants. Turnip mosaic virus (TuMV) is a virus threatening many economically important brassica crops. Especially, it has a very large host range among Brassica group plants and it can cause infection in 318 plant species from 156 genera. In the comprehensive studies conducted, dominant and recessive genes were identified in B. rapa (retr01, ConTR01, BcTuR3, rnt1, TuRBCH01, retr02, trs, TuMV-R, TuRB01b, TuRB07, TuRBCS01), in B. napus (TuRB01, TuRB02, TuRB03, TuRB04, TuRB05) and B. juncea (TuRBJU01, retr03). Studies conducted have shown that the genetic mechanism of resistance to TuMV is related to the host and pathogen strain. It is important to use the revealed resistance genes in breeding studies for Brassica species to prevent the disease. Identification and mapping of TuMV resistant genes in cabbage (B. oleracea), which is one of the important winter vegetables in the world and especially in Turkey, is required to prevent losses due to TuMV infection in cabbage. Therefore, studies on the resistance mechanism of TuMV in cabbages are needed. With the developments in genetics and molecular biology, it will be important to investigate the relationships between Brassica and TuMV at the molecular level, to understand the mechanism of resistance and to reveal new sources of resistance. This review has been prepared with the aim of bringing information about the genes and resistance mechanisms in Brassica species that have resistance to TuMV.
\end{abstract}

Keywords: Brassica, resistance genes, the mechanism of resistance, virus, Turnip mosaic virus 


\section{Giriş}

Brassicaceae familyasında sebze olarak tüketilen ve ekonomik öneme sahip bazı türler arasında; lahana, brokoli, karnabahar, yaprak lahana, şalgam, roka, turp, tere ile yağ ve biodizel olarak kullanılan kanola yer almaktadır (Martin ve ark., 2009). Dünyadaki lahana grubu sebzelerin üretim miktarlarında ilk sırada Çin bulunurken, Türkiye 765.276 ton üretim miktarı ile 12. sırada bulunmaktadır (Anonymous, 2018).

Brassicaceae familyası bitkileri birçok viral patojenine konukçuluk etmektedir (Raybould ve ark., 1999; Haas ve ark., 2002; Spence ve ark., 2007). Ancak Brassica grubu bitkilerde en yaygın viral etmenlerin başında Şalgam mozaik virüsü (Turnip mosaic virus-TuMV) yer almaktadır (Hunter ve ark., 2002). Potyviridae familyas1 Potyvirus cinsinin bir üyesi olan TuMV, dünya çapında Brassica türlerinde önemli ekonomik kayıplara neden olabilmektedir (Shattuck, 1992; Lydiate ve ark., 2014). TuMV; 9830-9835 nükleotitten oluşan tek sarmal, pozitif sens RNA içeren bir genoma sahiptir (Walsh ve ark., 2002). TuMV tek bir açık okuma çerçevesi (ORF) içermekte iken (Basso ve ark., 1994), daha sonra viral kodlu proteazlar tarafindan en az 10 daha küçük fonksiyonel polipeptide (P1, HC-Pro, P3, 6K1, C1, 6K2, VPg, NIa, Nib, CP) bölünmektedir (Riechmann ve ark., 1992; Walsh ve Jenner, 2002).

TuMV çok geniş konukçu dizisine sahip olup 156 cinse bağlı 318 bitki türünde enfeksiyon oluşturabilmektedir (Edwardson ve Christie, 1991). TuMV, ilk olarak 1921 yılında Amerika'da B. rapa'da, 1935 yılında Birleşik Krallık'da $B$. oleraceae'de (Smith, 1935) ve 1940 yılında Çin'de B. napus'da (Ling ve Yang, 1940) belirlenmiştir. Daha sonra Avrupa, Avustralya, Asya, Kuzey ve Güney Amerika kıtalarındaki birçok ülkede tespit edilmiş olup, dünya genelinde yaygın bir virüstür (Walkey ve Pink, 1988; Walsh ve Jenner, 2002; Coutts ve ark. 2007). TuMV ile mücadelede dayanıklı çeşitlerin kullanımı, virüs enfeksiyonunu tamamen engelleyerek veya ekonomik zarar seviyesinin altında tutarak ürün kayıplarını önlemektedir (Çandar ve Erkan, 2011).

$\mathrm{Bu}$ çalışmada; Brassica grubu bitki türlerinde önemli kayiplara neden olabilen TuMV'ye, dayanıklılık mekanizması ve dayanıklılıkla ilgili yapılan bazı çalışmalar hakkında kısa bilgiler verilmiştir.

\section{Brassica Türlerinde TuMV'ye Dayanıklılık}

Brassica türlerinde TuMV'ye dayanıklılıkla ilgili birçok çalışma yapılmış ve bu çalışmalar sonucunda dominant ve resesif dayanıkl111k kaynakları belirlenmiştir. Brassica türlerinde tespit edilen TuMV dayanıklık genlerinin çoğu, tek dominant genlerdir. $\mathrm{Bu}$ dominant dayanıklılık genleri dar spektrum dayanıklılık sağlamakla birlikte, yeni virüs 1rkları ile kolayca kırılabilmektedir (Rusholme ve ark., 2007). Brassicalarda birçok dayanıklılık geni tek dominant genleri içerse de poligenik ve resesif dayanıklılık örnekleri de bulunmaktadır.

TuMV’ye karşı, ilk Brassica dayanıklılık geni, kanoladan türetilen bir çeşitte bulunmuş olup; "TuMV Resistance in Brassica 01" olarak isimlendirilmiş ve bu isimlendirmenin baş harfleriyle TuRB01 olarak kısaltılmıştır. TuRB01 genini içeren konukçular, TuMV Patotip 1 izolatları ile inokule edilmiş, hiçbir konukçuda TuMV simptomu görülmemiş ve virüs tespit edilememiştir. TuRB01 dayanıklılık geninin $B$. napus A genomunun N6 kromozomunda bulunduğu belirtilmiştir (Walsh ve ark., 1999). TuMV Çin izolatı CHN1'in duyarlılık derecesini kontrol eden ikinci bir lokus TuRB02, C-genomundaki bağlantı grubu N14 üzerinde tanımlanmıştır. TuRB05 dayanıklılık geni, TuMV izolatlarına karşı sistemik yayılmayı sınırlayan bazı hipersensetif reaksiyonları kontrol ettiği belirlenmiştir. Liu ve ark. (1996) tarafindan 19 TuMV izolatı kullanılarak 3.000 Çin lahanası ( $B$. rapa var. pekinensis sub var. chinensis) hatt1 taranmıştır. Bu hatlardan sekiz tanesinin tüm TuMV izolatlarına karşı dayanıklı olduğu belirlenmiştir. Ayrıca bu çalışma ile 28 yeni dayanıklı hattın ortaya çıkmasına sağlanmıştır. Hughes ve ark. (2002) tarafindan 42 B. rapa ve $B$. napus hatlarını TuMV'nin 1,3 ve 4 patotip izolatlarına karşı test edilmiş; 14 hattın her üç patotipe, 8 hattın iki patotipe ve 9 hattın ise bir patotipe dayanıklı olduğu belirlenmiştir.

TuMV'nin tüm genom sekansı ilk defa Kanadalı bilim adamları Nicolas ve Laliberte (1992) tarafından yayınlanmıştır. Yapılan kapsamlı çalışmalarda B. rapa, B. oleraceae, B. juncea, B. napus'u içeren Bassicalarda TuMV'ye dayanıklılık kalıtımının farklı biçimlerde olduğu ortaya çıkmıştır. TuMV'ye dayanıklılığın genetik mekanizması konukçuya ve patojen ırkına bağlı olduğu bilinmektedir.

TuMV, üç Brassica dayanıklılık genine yönelik avirülens belirleyiciler TuRB01/TuRB01b için CI proteini iken (Jenner ve ark., 2000; Walsh ve ark., 2002), TuRB04 ve TuRB05 için P3 ve CI (sitoplazmik cisimciği) proteinleridir (Şekil 1) (Jenner ve ark., 2002).

Potyvirüslerin, replikasyonu ve yayılması için eIF4E ve eIF (iso) 4E gibi ökaryotik translasyon 
başlatma faktörleri (eIF'ler) gerekmektedir. Bitki ökaryotik translasyon başlatma faktörü 4E (eIF4E) familyası üyeleri, bazı potyvirüslerin enfeksiyonunda kritik bir rol oynadığı bilinen konukçu faktörlerdir. $\mathrm{Bu}$ gen ailesindeki mutasyonlar resesif dayanıklılığın ortaya çıkmasına neden olup, ıslah çalışmalarında kullanılmaktadirlar (Robaglia ve Caranta, 2006; Wang ve Krishnaswamy, 2012). TuMV, konukçu bitkiyi enfekte ettiğinde translasyonun başlaması için, eIF4E'nin, genom ile bağlantılı viral protein (VPg)'le etkileşime girmesi gerekmektedir (Beauchemin ve ark., 2007; Cotton ve ark., 2009).

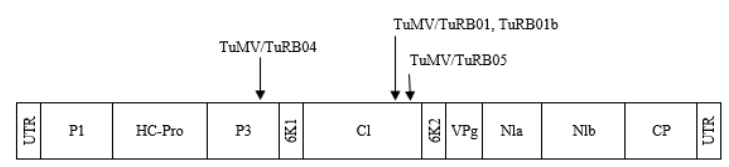

Şekil 1. Bazı TuMV dayanıklılık genleri ve ilişkili proteinler (Jenner ve ark., 2002)

\subsection{Brassica rapa'da TuMV'ye dayanıklılık}

Şalgam bitkisinin TuMV'ye dayanıklığıyla ilgili bir çok çalışma yapılmış ve dayanıklılığın resesif ve dominant olarak kontrol edildiği belirlenmiştir (Niu ve ark., 1983; Yoon ve ark., 1993). B. rapa'da dayanıklılık sağlayan genlere ait bilgiler Tablo 1'de verilmiştir.

Yoon ve ark. (1993), tarafindan Çin lahanalarında dayanıklı $0-2$ hattı ile hassas 3 hattı (E-7, E-9 ve FL-9) melezlenmiş, daha sonra TuMV'nin $\mathrm{C}_{4}-\mathrm{C}_{5}$ strainleri ile inokulasyonu gerçekleştirmiştir. Yapılan testler sonucunda iki resesif gen, TuMV-C 4 ve TuMV-C 5 strainlerine karşı dayanıklılık gösterdiği belirlenmiştir.

Çin lahanası çeşidinden elde edilen dayanıklılığın, TuRB01 ile neredeyse tamamen aynı özgüllük ve mekanizmaya sahip olduğu belirtilmiştir (Walsh ve ark., 2002). Rusholme ve ark. (2007) tarafindan dominant gen ConTR01 ile birlikte R4 kromozomunun üst kismında resesif bir gen (retr01) taranmış ve bu genin ConTR01'e göre epistatik olduğu bildirilmiştir. Aynı araştırıcılar ayrıca $B$. rapa hattı RLR22 ile yapmış oldukları çalışmada; bu hattın sekiz farklı TuMV izolatına karşı dayanıklı olduğunu belirlemişlerdir.

Kassem ve Walsh (2008) yaptıkları çalışmada, başlica patotipleri temsil eden yedi adet TuMV izolatına (UK1, CHN 5, CZE 1, CDN 1, GBR 6, POL 1 ve UK 4) karşı yüksek dayanıklılık gösteren bir $B$. rapa hattını tanımlamışlardır. Araştırıcılar tarafından yedi TuMV izolatı, bitkilere inokule edilmiştir. İnokule edilen bitkilerin UK1 TuMV izolatına dayanıklı, CHN5 izolatına ise hassas olduğu belirlenmiştir. Ayrıca GBR6'ya dayanıklılığın tek bir dominant gen tarafından, UK4'e dayanıklılığın ise iki veya daha fazla dominant gen tarafından kontrol edildiği bildirilmiştir.

İki Çin lahanası Y177212 (TuMV'ye hassas) ve Y195293 (TuMV'e dayanıklı) hattından elde edilen, 183 çift haploid (DH)'in, TuMV dayanıklılığı ile ilgili kantitatif özellik lokuslarının (QTL) haritalandırılması amacıyla yapılan çalışmada; hatlar TuMV C4 1rkı ile inoküle edilmiş ve R03, R04 ve R06 gruplarıyla bağlantılı, üç kantitatif karakter lokusu (QTL) olduğu belirlenmiştir (Zhang ve ark., 2009).

Ma (2010) baş oluşturmayan Çin lahanalarından elde ettiği BcTuR3 geni üzerine yaptığı çalışmada, Çin lahanaları TuMV ile inoküle edildikten sonra, enfekte olmuş yapraklarda ve sürgünlerde BcTuR3 transkriptinin, hızlı bir şekilde biriktiğini belirlemiştir. Bu veriler, BcTuR3 geninin, TuMV enfeksiyonuna karşı bitki dayanıklılığında rol oynayabileceğini göstermiştir.

B. rapa'da bir başka dayanıklılı geni, kromozom (A6) bölgesinde 2.9-cM aralığında tanımlanmış ve TURB01b olarak isimlendirilmiştir (Lydiate ve ark., 2014). Araştırmacilar, Brassicalarda TuMV'ye karşı haritalanmış ilk dominant gen olan TuRB01 ile TuRB01b'nin aynı dayanıklılık lokusundaki benzer alelleri temsil ettiğini bildirmişlerdir. Çin'de, TuMV C4 izolatına karşı yapılan çalışmada; 80122, 80124, BP058, 80186 ve 2079 numaralı beş Çin lahanası hattının

Tablo 1. B. rapa'daki TuMV'ye dayanıklılık genleri (Li ve ark., 2019)

\begin{tabular}{lcccl}
\hline Dayan1kl1lik geni & Tür (Genom) & Hat & Patotip / İzolat & Kaynaklar \\
\hline retr01 & B. rapa (A) & RLR22 & $1,3,4,7,8,9,12$ & Rusholme ve ark. (2007) \\
ConTR01 & B. rapa (A) & RLR22 & $1,3,4,7,8,9,12$ & Rusholme ve ark. (2007) \\
BcTuR3 & B. rapa (A) & Duanbaigeng & - & Ma ve ark. (2010) \\
rnt1 & B. rapa (A) & AS9 & UK1 & Fujiwara ve ark. (2011) \\
TuRBCH01 & B. rapa (A) & Q048 & C5 & Wang ve ark. (2011) \\
retr02 & B. rapa (A) & BP8407 & C4 & Qian ve ark. (2013) \\
trs & B. rapa (A) & SB18/SB22 & CHN2, CHN3, CHN4, CHN5 & Kim ve ark. (2013) \\
TuMV-R & B. rapa (A) & VC40 & - & Chung ve ark. (2014 \\
TuRB01b & B. rapa (A) & TD34-S1 & 1 & Lydiate ve ark. (2014) \\
TuRB07 & B. rapa (A) & VC1/VC40 & C4 & Jin ve ark. (2014) \\
TuRBCS01 & B. rapa (A) & 8407 & C4 & Li ve ark. (2015) \\
\hline
\end{tabular}


dayanıklı ve üç hattın ise aşırı hassas (80403, 80461 ve 80425 ) olduğu belirlenmiştir (Qian ve ark., 2013; Li ve ark., 2016).

Moleküler biyolojide meydana gelen gelişmelerle birlikte, TuMV-R, TuRB07, TuRBCS01 gibi yeni dominant dayanıklılık genleri ortaya çıkarılmıştır (Chung ve ark., 2014; Jin ve ark., 2014; Li ve ark., 2015; Gao ve ark., 2016). Qian ve ark. (2013) tarafindan, TuMV C4 izolatı ve resesif dayanıklılık geni retr02 ile ilgili yapılan çalışma sonucunda, B. rapa genonumda elF (iso) $4 \mathrm{E}$ proteinin kodlayan genin kromozom A4 üzerinde bulunduğunu bildirmişlerdir. Kim ve ark. (2013) tarafından, A4 bölgesi üzerinde bulunan ve TuMV'nin dört farklı izolatına (CHN2, CHN3, CHN4, CHN5) karşı dayanıklık ortaya koyduğu belirlenen trs geni haritalandırılmış ve araştırıcılar tarafından trs'nin retr02 veya başka bir allele sıkıca bağlı diğer bir resesif dayanıklılık geni olabileceği bildirilmiştir.

Potyvirüslerde resesif dayanıklılık, translasyon başlama faktörleri (elF) ile genom bağlantılı viral protein (VPg)'in arasındaki ilişkini bozulması ile ortaya çıkmaktadır. Kim ve ark. (2014), B. rapa'nın eIF (iso) 4E'lerinde bulunan W95L, K150L ve W95L/K150L aminoasitlerinde meydana gelen mutasyon sonucunda elF(iso) $4 \mathrm{E}$ ile VPg arasındaki etkileşimin kestiğini belirtmişlerdir. TuMV'ye hassas yabani Çin lahanası çeşidinde eIF(iso) 4E'de meydana gelen mutasyonların TuMV'nin birçok ırkına dayanıklılık sağlayabildiğini belirtmişlerdir. Nellist ve ark. (2014), retr01/retr02 dayanıkl1lık genlerinin $B$. rapa'da eIF(iso) 4E'yi kodlayabildiğini bildirmişlerdir. TuMV C4 izolatlarına karşı yeni bir dominant dayanıklılık geni TuRB07, B. rapa hatt1 VCl'de A06 kromozomunun üzerinde haritalandırılmış ve bu dayanıklılığın tek bir gen tarafindan kontrol edildiği bildirilmiştir (Jin ve ark., 2014).

\subsection{Brassica napus'ta TuMV'ye dayanıklılık}

Yağ ve biyodizel sanayinin ham maddesi olan B. napus'ta TuMV'ye dayanıklılıkla ilgili yapılan çalışmalar sonucunda, farklı dayanıklılık formları belirlenmiş ve birkaç gen haritalandırılmıştır (Tablo 2). İlk dayanıklılık geni olan TuRB01'i $B$. napus A genomunundaki N6 bağlantı grubu üzerinde haritalandırılmıştır. $\mathrm{Bu}$ sonuçlar
B. napus'ta genin $B$. rapa kaynaklı olduğunu göstermektedir. TuMV'nin birçok izolat1, dayan1kl1lık geni TuRB01'e sahip olan B. napus hatlarında enfeksiyon oluşturamamaktadır. TuRB02 geni $B$. napus'ta TuMV'ye dayanıklılık sağlayan genlerden biridir. B. napus'ta CHN1 izolatına karşı dayanıklılık sağlamakta olup C genomu bağlantı grubu, N14 üzerinde tanımlanmıştır (Walsh ve ark., 1999).

Lehmann ve ark. (2003), TuMV'ye dayanıklığın etkinliğini netleştirmek için TuMV'nin kapsid protein (CP) genini kanolaya aktarmışlar ve CP'nin dayanıklılığ1 değiştirebileceğini ve TuMV'ye geniş spektrumlu dayanıklılık sağlayabileceğini saptamışlardır. TuRB03 dayanıklık geni, B. napus 'un 22S hattında tanımlanmıştır (Walsh, 1989). CP gen stratejisi ile kanola ve Çin lahanasında TuMV'ye dayanıklılığın arttırıldı ̆̆ proteininin B. napus'taki TuMV simptomlarının şiddetinde rolü olduğu bilinmektedir (Jenner ve ark., 2003).

B. napus hatlarında TuMV'ye karşı tanımlanan dominant dayanıklılık genleri, bazı izolatlarına karşı etkili iken, bazı izolatlarına karşı etkili değildir. UK1 izolatına karşı B. napus hatlarından R4, 165 ve N-o-1 dayanıklılık sağlamaktadır. Mutant bir UK1 ile belirlenen $B$. napus hatlarına inokulasyon yapılmıştır. TuRB01 dayanıklılık genlerine sahip olan R4 ve N-o-1 hatları mutant UK1'e dayanıklık göstermeyip enfekte olmuştur. Daha sonra yapılan dizi analizinden CI proteinindeki bir amino asidi etkileyen tek bir nükleotit ile UK1'den farklı olmuştur. İkinci mutant, aynı gende farklı bir mutasyona sahiptir. Aynı çalışmada TuRB04 ve TuRB05 için bu dayanıklılık genlerine sahip hat olan 165 'e mutant UK1 izolatı inokule edilmiş ve mutant UK1 izolatının bu dayanıklı hatta enfeksiyon yapabilme yeteneği kazandığı bildirilmiştir. Mutant izolatın tüm gen genom sekans analizinde, UK1 izolatından 16 nükleotidin farklı olduğu belirlenmiştir. CI proteini TuRB01 için, P3 proteini ise TuRB04 için bir TuMV patojenik belirleyiciler olarak işlem görmektedir (Jenner ve ark., 2002).

Hughes ve ark. (2003) tarafindan yapilan bir çalışmada, TuMV patotip 4'e dominant ve monogenik dayanıklılığı belirlemek amacıyla

Tablo 2. B. napus'taki TuMV'ye dayanıklılık genleri (Li ve ark., 2019)

\begin{tabular}{llccl}
\hline Dayan1kl1lık geni & Tür $($ Genom) & Hat & Patotip/ İzolat & Kaynaklar \\
\hline TuRB01 & B. napus (A) & N-o-9 & 1 & Walsh ve ark. (1999) \\
TuRB02 & B. napus (C) & N-o-9 & CHN1, JPN1 & Walsh ve ark. (1999) \\
TuRB03 & B. napus (A) & 22 S & CDN1 & Hughes ve ark. (2003) \\
TuRB04 & B. napus (A) & 165 & 1,3 & Jenner ve ark. (2002, 2003) \\
TuRB05 & B. napus (A) & 165 & 1,3 & Jenner ve ark. (2002, 2003) \\
\hline
\end{tabular}


dayanıklı ve hassas $B$. napus'tan geri melezleme yapılmış ve kromozom N6 üzerindeki TuRB03 dayanıklılık genleri haritalanmıştır. TuRB03'ün diğer TuMV izolatları ile test edilmesi sonucu patotip 4 izolatlara karşı etkili olmadığ1 belirlenmiştir.

\subsection{Brassica oleracea'da TuMV'ye dayanıklılı}

$\mathrm{Bu}$ bitki ile yapılan çalışmalarda; İngiltere, Almanya, Danimarka ve Yunanistan'a ait TuMV izolatları kullanılarak, dört beyaz lahana çeşidi test edilmiş ve üç çeşit (Decema Extra, Vitala, Winter White III) oldukça dayanıklı, bir çeşit (Polinius) ise oldukça hassas bulunmuştur (Walkey ve Pink, 1988). Gen bankası koleksiyonundan B. oleracea temsil etmek üzere seçilen, C genom tipinde 114 aksesiyonun testlenmesi sonucunda ise hiçbir önemli dayanıklılık kaynağının bulunmadığı bildirilmiştir (Walsh ve Jenner, 2002). Başka bir çalışmada, lahana hattı 84075 üzerinde yapılan araştırmada ise, TuR2 geninin TuMV'ye karş1 dayanıklılık kaynağı olabileceği bildirilmiştir (Cao ve ark., 2002).

\subsection{Brassica juncea'da TuMV'ye dayanıkıık}

B. juncea; iki diploid türünün, $B$. rapa (AA) ve B. nigra (BB) genomlarını içeren, AABB genomlu bir amfibidiloid bitki türüdür (Wang, 2016). Çeşitlerinin çoğu TuMV'ye oldukça hassastır, bu da ciddi ürün kayıplarına neden olmaktadır (Wang, 2016). Yapılan çalışmalarda, B. juncea'da TuMV enfeksiyonlarına karşı dayanıklılık sağlayan TuRBJU01 (dominant) ve retr03 (resesif) genleri haritalandırılmıştır (Tablo 3). TuRBJU01 geni $B$. juncea'larda TuMV'ye karşı sistemik hipersensetif reaksiyona neden olmaktadır. Nyalugwe ve ark. (2015a) TuMV'ye dayanıklılı sağlayan TuRBJU01 geninin tanımlanmasını amaçladıkları çalışmada, TuMV patotip 8 izolatını, 69 B. juncea hattına inokule etmişler; araştırmacılar, bu genin, B. napus'da bulunan TuRB01 ve TuRB03 genleri ile ilişkili olduğunu bildirmişlerdir.

B. juncea'nın TuMV'ye hassas hattı JM 06006 ile dayanıklı hattı Oasis $\mathrm{Cl}$ melezlenmiş F3 generasyonunda elde edilen melezler, 10 farklı Avustralya TuMV izolatı SW-1, NSW-5 (patotip 7), NSW-2, NSW-6 (patotip 1), WA-Ap, WA-Ap1

Tablo 3. B. juncea' daki dayanıklılık genleri (Li ve ark., 2019)

\begin{tabular}{lcccl}
\hline Dayanıkl1lk geni & Tür $($ Genom $)$ & Hat & Patotip/ İzolat & Kaynaklar \\
\hline TuRBJU01 & B. juncea & Oasis Cl & 8 (WA-Ap1) & Nyalugwe ve ark. (2015a) \\
retr03 & B. juncea $(\mathrm{A})$ & VC029 & ZJ & Shopan ve ark. (2017) \\
\hline
\end{tabular}

(patotip 8), NSW-3, NSW-4 (yeni patotip), 12.1 ve 12.5 (B. napus'ta dayanıklı kırıcı izolat) ile inokule edilmiştir. TuRBJU 01 geni, izolatlat 12.1 ve 12.5 'e karşı daha az etkili bulunmuştur. Bu nedenle B. juncea'nın TuMV'ye dayanıklılık 1slah çalışmalarında TuRBJU 01 geni önemli olmaktadır (Nyalugwe ve ark., 2015b). Shopan ve ark. (2017), dayanıklı/hassas bitki hatlarının dizi analizleri yoluyla TuMV'ye dayanıklı ve hassas $B$. juncea hatları ile ayrıștırma popülasyonları geliştirmişlerdir. Elde edilen sonuçlara göre, TuMV izolatı ZJ'ye dayanıklılığın tek bir resesif gen retr03 tarafından kontrol edildiğini belirlemişlerdir. Ayrıca bazı hardal hatlarında TuMV'ye karşı doğal monojenik resesif dayanıklılık bulunduğu bildirilmiştir. Cao ve ark. (2008) tarafından yapılan başka bir çalışmada ise lahanadan izole edilen TuR2 geni A. tumefaciens aracılığıyla $B$. juncea'ya aktarılmıştır. Transgenik bitkilerin ilk nesillerindeki TuR2 geninin dominant monojenik kalıtım gösterdiğini ve TuMV'ye dayanıklılık fonksiyonuna sahip olduğunu saptamışlardır.

\section{Sonuçlar}

Kışlık sebze, yağ ve biyoyakıt kullanım amacıyla üretimi yapılan Brassica türlerinde enfeksiyona neden olan en önemli viral patojen TuMV'dir. TuMV, Türkiye'nin de dâhil olduğu birçok ülkede tespit edilmiştir. Bitkilerde virüs kaynaklı hastalıklara karşı, kimyasal mücadelenin olmayışı, viral patojenlere karşı farklı mücadele yöntemlerinin kullanımını zorunlu kılmaktadır. Bitki virüs hastalıklarıyla etkili mücadele yöntemlerinin başında dayanıklı çeşit kullanımı gelmektedir.

Araştırıcılar bazı Brassica türlerinde TuMV'ye dayanıklılı̆̆1 sağlayan dominant ve resesif karakterde bazı genler tespit etmiş ve tanılamışlardır. B. napus, B. rapa ve B. juncea'da TuMV izolatlarına karşı çeşitli dayanıklılık genleri tanımlanmıştır.

Dayanıklılık genlerinin tanımlanıp, 1slah çalışmalarında yeni çeşitlere aktarılmasıyla dayanıklı çeşitler ortaya çıkabilmektedir. Dayanıklılık sağlayan genler daha çok $B$. rapa'da tespit edilmiştir. Özellikle dünyada ve Türkiye'de önemli kışlık sebzelerden biri olan lahanada TuMV'ye dayanıklı genlerin tanımlanarak, haritalanması lahanada TuMV enfeksiyona bağlı ürün kayıplarının önlenmesi için gereklidir. $\mathrm{Bu}$ nedenle lahanada TuMV'ye dayanıklılık mekanizmasıyla ilgili çalışmalara ihtiyaç vardır. Son y1llarda genetik ve moleküler biyolojide 
yaşanan gelişmelerle Brassica ve TuMV arasındaki ilişkinin moleküler düzeyde araştırılması, dayanıklılık mekanizmasının anlaşılması ve yeni dayanıklılık kaynaklarının ortaya çıkması açısından önemlidir. Bazı Brassica türlerinde, TuMV dayanıklılığının tek gen tarafindan kontrol edilmesi ve bunların çabuk kırılmasından dolayı, dayanıklılıkla ilgi çalışmaların daha etkin bir şekilde yapılması gereklidir. Brassica türlerinde konukçu ve TuMV arasındaki ilişkinin anlaşılması gelecek yıllarda, TuMV ile mücadele için yapılacak olan araştırmalara yol gösterecektir.

\section{Kaynaklar}

Anonymous, 2018. Production Quantity of Cabbage and other Brassicas. (http://www.fao.org/faostat/en/\#data /QC), (Erişim tarihi: 08.05.2020).

Basso, J., Dallaire, P., Charest, P.J., Devantier, Y., Laliberte, J.F., 1994. Evidence for an internal ribosome entry site within the 50 non-translated region of Turnip mosaic potyvirus RNA. Journal of General Virology, 75(11): 3157-3165.

Beauchemin, C., Boutet, N., Laliberte, J.F., 2007. Visualization of the interaction between the precursors of $\mathrm{Vpg}$, the viral protein linked to the genome of Turnip mosaic virus, and the translation eukaryotic initiation factor iso $4 \mathrm{e}$ in planta. Journal of Virology, 81(2): 775-782.

Cao, B.H., Lei, J.J., Xiang, C.B., Chen, G.J., Zeng, G.P., David, O., Zhao, S., Lu, L.L., 2008. The function 1dentification of the candidate disease-resistance gene in cabbage. Agricultural Sciences in China, 7(3): 314-320.

Cao, B.H., Song, H.Y., Lei, J.J., Song, M., Yang, Z.H., 2002. Cloning a gene related to resistance to TuMV in cabbage. Acta Genetica Sinica, 29(7): 646-652.

Chung, H., Jeong, Y.M., Mun, J.H., Lee, S.S., Chung, W.H., Yu, H.J., 2014. Construction of a genetic map based on high-throughput SNP genotyping and genetic mapping of a TuMV resistance locus in Brassica rapa. Molecular Genetics \& Genomics, 289(2): 149-160.

Cotton, S., Grangeon, R., Thivierge, K., Mathieu, I., Ide, C., Wei, T., Wang, A., Laliberte, J.F., 2009. Turnip mosaic virus RNA replication complex vesicles are mobile, align with microfilaments, and are each derived from a single viral genome. Journal of Virology, 83(20): 10460-10471.

Coutts, B.A., Walsh, J.A., Jones, R.A.C., 2007. Evaluation of resistance to Turnip mosaic virusin Australian Brassica napus genotypes. Australian Journal of Agricultural Research, 58(1): 67-74.

Çandar, A., Erkan, S., 2011. Bitkilerde viral etmenlere karsı genetik dayanıklılık mekanizmaları. Elektronik Mikrobiyoloji Dergisi, 9(3): 13-27.

Edwardson, J.R., Christie, R.G., 1991. The Potyvirus Group. University of Florida, Florida Agricultural Experiment Station, Monograph Series, 16: 1244.
Fujiwara, A., Inukai, T., Kim, B.M., Masula, C., 2011. Combinations of a host resistance gene and the CI gene of Turnip mosaic virus differentially regulate symptom expression in Brassica rapa cultivars. Archives of Virology, 156(9): 1575-1581.

Gao, H., Zeng, Q., Zhang, Z., Zhao, Z., Pei, Y., Liu, S., Li, Y., Liu, Y., Liu, X., Song, X., Li, Q., 2016. The development of molecular markers closely linked to TuMV resistance gene TuRBCS01 in Chinese cabbage (Brassica campestris ssp. pekinensis). Journal of Agricultural Biotechnology, 24(2): 196205.

Haas, M., Bureau, M., Geldreich, A., Yot, P., Keller, M., 2002. Cauliflower mosaic virus: Still in the news. Molecular Plant Pathology, 3(6): 419-429.

Hughes, S.L., Green, S.K., Lydiate, D.J., Walsh, J.A., 2002. Resistance to Turnip mosaic virus, in B. rapa, and $B$. napus, and the analysis of genetic inheritance in selected lines. Plant Pathology, 51(5): 567-573.

Hughes, S.L., Hunter, P.J., Sharpe, A.G., Kearsey, M.J., Lydiate, D.J, Walsh, J.A., 2003. Genetic mapping of the novel Turnip mosaic virus resistance gene TuRB03 in Brassica napus. Theoretical and Applied Genetics, 107(7): 1169-1173.

Hunter, P.J., Jones, J.E., Walsh, J.A., 2002. Involvement of Beet western yellow virus, Cauliflower mosaic virus and Turnip mosaic virusin internal disorders of stored white cabbage. Phytopathology, 92(8): 816826.

Jenner, C.E., Sánchez, F., Nettleship, S.B., Foster, G.D., Ponz, F., Walsh, J.A., 2000. The cylindrical inclusion gene of Turnip mosaic virus encodes a pathogenic determinant to the Brassica resistance gene TuRB01. Molecular Plant-Microbe Interactions, 13(10): 1102-1108.

Jenner, C.E., Tomimura, K., Ohshima, K., Hughes, S.L., Walsh, J.A., 2002. Mutations in Turnip mosaic virus P3 and cylindrical inclusion proteins are separately required to over come two Brassica napus resistance genes. Virology, 300(1): 50-59.

Jenner, C.E., Wang, X., Tomimura, K., Ohshima, K., Ponz, F., Walsh, J.A., 2003. The dual role of the potyvirus P3 protein of Turnip mosaic virus as a symptom and a virulence determinant in brassicas. Molecular Plant-Microbe Interactions, 16(9): 777784.

Jin, M., Lee, S.S., Ke, L., Kim, J.S., Seo, M.S., Sohn, S.H., Park, B.S. Bonnema, G., 2014. Identification and mapping of a novel dominant resistance gene, TuRB07 to Turnip mosaic virus in Brassica rapa. Theoretical and Applied Genetics, 127(2): 509-519.

Kassem, A., Walsh, JA., 2008. Characterising resistance to Turnip mosaic virus (TuMV) in turnip (Brassica rapa var. rapa). Arab Journal of Plant Protection, 26(2): 168-172.

Kim, J., Kang, W.H., Hwang, J., Yang, H.B., Dosun, K., Oh, C.S., Kang, B.C., 2014. Transgenic Brassica rapa plants over-expressing eIF(iso) 4E variants show broad-spectrum Turnip mosaic virus (TuMV) resistance. Molecular Plant Pathology, 15(6): 615626. 
Kim, J., Kang, W.H., Yang, H.B., Park, S., Jang, C.S., Yu, H.Y., Kang, B.C., 2013. Identification of a broadspectrum recessive gene in Brassica rapa and molecular analysis of the eIF4E gene family to develop molecular markers. Molecular Breeding, 32(2): 385-398.

Lehmann, P., Jenner, C.E., Kozubek, E., Greenland, A.J., Walsh, J.A., 2003. Coat protein-mediated resistance to Turnip mosaic virus in oilseed rape (Brassica napus). Molecular Breeding, 11(2): 83-94.

Li, G., Lv, H., Zhang, S., Zhang, S., Li, F., Zhang, H., Qian, W., Fang, Z., Sun, R., 2019. Plant pathology TuMV management for brassica crops through host resistance: Retrospect and prospects. Plant Pathology, 68(6): 1035-1044.

Li, G.L., Qian, W., Zhang, S., Zang, S.F., Li, F., Zhang, H., Wu, J., Wang, W.W., Sun, R.F. 2016. Development of gene-based markers for the Turnip mosaic virus resistance gene retr02 in Brassica rapa. Plant Breeding, 135(4): 466-470.

Li, Q., Zhang, X., Zeng, Q., Zhang, Z., Liu, S., Pei, Y., Wang, S., Liu, X., Xu, W., Fu, W., Zhao, Z., Song, $X$., 2015. Identification and mapping of a novel Turnip mosaic virus resistance gene TuRBCS01 in Chinese cabbage (Brassica rapa L.). Plant Breeding, 134(2): 221-225.

Ling, L., Yang, J.Y., 1940. A mosaic disease of rape and other cultivated crucifers in China. Phytopathology, 30(4): 338-342.

Liu, X.P., Lu, W.C., Liu, Y.K., Wei, S.Q., Xu, J.B., Liu, Z.R., Zhang, H.J., Li, J.L., Ke, G.L., Yao, W.Y., Cai, Y.S., Wu, F.Y., Cao, S.C., Li, Y.H., Xie, S.D., Lin, B.X., Zhang, C.L., 1996. Occurrence and strain differentiation on Turnip mosaic potyvirus and sources of resistance in Chinese cabbage in China. Acta Horticulturae, 407(55): 431-440.

Lydiate, D.J., Pilcher, R.L., Higgins, E.E., Walsh, J.A., 2014. Genetic control of immunity to Turnip mosaic virus (TuMV) pathotype 1 in Brassica rapa (Chinese cabbage). Genome, 57(8): 419-425.

Ma, J.F., Hou, X.L., Xiao, D., Qi, L., Wang, F., Sun, F., Wang, Q., 2010. Cloning and characterization of the BcTUR3, gene related to resistance to Turnip mosaic virus (TuMV) from non-heading Chinese cabbage. Plant Molecular Biology Reporter, 28(4): 588-596.

Martin, E., Güler, B., Karabulut, B., Özdemir, A., 2009. Türkiye'de yetişen Cheiranthus cheiri L. (Brassicaceae) türünün karyotip analizi. Türkiye Biyoloji Bilimleri Araştırma Dergisi, 2(1): 13-16.

Nellist, C.F., Wei, Q., Jenner, C.E., Moore, J.D., Zhang, S., Wang, X., Briggs, W.H., Barker, G.C., Sun, R., Walsh, J.A., 2014. Multiple copies of eukaryotic translation initiation factors in Brassica rapa facilitate redundancy, enabling diversification through variation in splicing and broad spectrum virus resistance. The Plant Journal, 77(2): 261-268.

Nicolas, O., Laliberté, J.F., 1992. The complete nucleotide sequence of turnip mosaic potyvirus RNA. Journal of General Virology, 73(11): 27852793.
Niu, X.K., Leung, H., Williams, P.H., 1983. Sources and nature of resistance to downy mildew and Turnip mosaic in Chinese cabbage. Journal of the American Society for Horticultural Sciences, 108(5): 775-778.

Nyalugwe, E.P., Barbetti, M.J., Jones, R.A.C., 2015 a. Studies on resistance phenotypes to Turnip mosaic virus, in five species of Brassicaceae, and identification of a virus resistance gene in Brassica juncea. European Journal of Plant Pathology, 141(4): 647-666.

Nyalugwe, E.P., Jones, R.A.C., Barbetti, M.J., Kehoe, M.A., 2015b. Biological and molecular variation amongst Australian Turnip mosaic virus isolates. Plant Pathology, 64(5): 1215-1223.

Qian, W., Zhang, S.J., Li, F., Zhang, H., Wu, J., Wang, X., Walsh, J.A., Sun, R., 2013. Mapping and candidate-gene screening of the novel Turnip mosaic virus resistance gene retr02 in Chinese cabbage (Brassica rapa L.). Theoretical and Applied Genetics, 126(1): 179-188.

Raybould, A.F., Maskell, L.C., Edwards, M.L., Cooper, J.I., Gray, A.J., 1999. The prevalence and spatial distribution of viruses in natural populations of Brassica oleracea. The New Phytologist, 141(2): 265-275.

Riechmann, J.L., Lain, S., Garcia, J.A., 1992. Highlights and prospects of potyvirus molecular biology. Journal of General Virology, 73(1): 1-16.

Robaglia, C., Caranta, C., 2006. Translation initiation factors: a weak link in plant RNA virus infection. Trends in Plant Science, 11(1): 40-45.

Rusholme, R.L., Higgins, E.E., Walsh, J.A., Lydiate, D.J., 2007. Genetic control of broad-spectrum resistance to Turnip mosaic virus in Brassica rapa (Chinese cabbage). Journal of General Virology, 88(11): 3177-3186.

Shattuck, V.I., 1992. The biology, epidemiology and control of Turnip mosaic virus. Plant Breeding Reviews, 14: 199-238.

Shopan, J., Mou, H., Zhang, L., Zhang, C., Ma, W., Walsh, J.A., Hu, Z., Yang, J., Zhang, M., 2017. Eukaryotic translation initiation factor 2B-beta (eIF2Bb), a new class of plant virus resistance gene. The Plant Journal, 90(5): 929-940.

Smith, K.M., 1935. A virus disease of cultivated crucifers. Annals of Applied Biology, 22(2): 239242.

Spence, N.J., Phiri, N.A., Hughes, S.L., Mwaniki, A., Simons, S., Oduor, G., Chacha, D., Kuria, A., Ndirangu, S., Kibata, G.N., Marris, G.C., 2007. Economic impact of Turnip mosaic virus, Cauliflower mosaic virus and Beet mosaic virus in three Kenyan vegetables. Plant Pathology, 56(2): 317-323.

Walkey, D.G.A., Pink, D.A.C., 1988. Reactions of white cabbage (Brassica oleracea var. capitata) to four different strains of Turnip mosaic virus. Annals of Applied Biology, 112(2): 273-284.

Walsh, J.A., 1989. Genetic control of immunity to Turnip mosaic virus in winter oilseed rape (Brassica napus ssp. oleifera) and the effect of foreign isolates 
of the virus. Annals of Applied Biology, 115(1): 8999.

Walsh, J.A., Jenner, C.E., 2002. Turnip mosaic virus and the quest for durable resistance. Molecular Plant Pathology, 3(5): 289-300.

Walsh, J.A., Rusholme, R.L., Hughes, S.L., Jenner, C.E., Bambridge, J.M., Lydiate, D.J., Green, S.K., 2002. Different classes of resistance to Turnip mosaic virus in Brassica rapa. European Journal of Plant Pathology, 108(1): 15-20.

Walsh, J.A., Sharpe, A.G., Jenner, C.E., Lydiate D.J., 1999. Characterisation of resistance to Turnip mosaic virus in oilseed rape (Brassica napus) and genetic mapping of TuRB01. Theoretical and Applied Genetics, 99(7): 1149-1154.

Wang, A., Krishnaswamy, S., 2012. Eukaryotic translation initiation factor $4 \mathrm{E}-$ mediated recessive resistance to plant viruses and its utility in crop improvement. Molecular Plant Pathology, 13(7): 795-803

Wang, T., 2016. Resistance to Turnip mosaic virus (TuMV) in Brassica juncea and introgression of resistance from Brassica rapa, Brassica napus and Brassica nigra into Brassica juncea. $\mathrm{PhD}$ thesis, University of Warwick.

Wang, X.H., Li, Y., Chen, H.Y., 2011. A linkage map of pak-choi (Brassica rapa ssp. chinensis) based on AFLP and SSR markers and identification of AFLP markers for resistance to TuMV. Plant Breeding, 130(2): 275-277.

Yoon, J.Y., Green, S.K., Opena, R.T., 1993. Inheritance of resistance to Turnip mosaic virus in Chinese cabbage. Euphytica, 69(1): 103-108.

Zhang, X.W., Yuan, Y.X., Wang, X.W., 2009. QTL mapping for TuMV resistance in Chinese cabbage (Brassica campestris L. ssp. pekinensis (Lour.) Olssom). Acta Horticulturae Sinica, 36(5): 731-736. 